\title{
Herbert James French
}

\section{Howe Memorial Lecturer}

Herbert J. French (Member 1934), vice president of the International Nickel Co. Inc., assistant vice president of the International Nickel Co. of Canada Ltd., and AIME Howe Memorial Lecturer for 1956, died in Rochester, Minn. on Aug. 17, 1955, after a long illness.

Before his death, Mr. French had laid the foundation of research on which the Howe Memorial Lecture (p. 770) was based. His associates at Inco, O. O. Miller and J. W. Sands, were able to complete the project, present the lecture, and prepare it for publication, following $\mathrm{Mr}$. French's general outline.

Born in New York on May 27, 1893, he graduated from the School of Mines, Columbia University, with a degree in metallurgical engineering in 1915. Mr. French gained his early engineering experience with the American Smelting and Refining Co., serving as a chemist and assayer at the company's Murray, Utah, installations. He later returned east and became a metallurgical engineer for the General Vehicle Co., Long Island City, N. Y., a subsidiary of the General Electric Co. In 1917 Mr. French was appointed civilian inspector of materials for the U. S. Army Signal Corps, and continued this work when it was later absorbed into the Bureau of Aircraft Production. Subsequently he was appointed district inspector in Philadelphia for the Pittsburgh (Ordnance Metallurgical) office, later transferring to Pittsburgh.

After World War I Mr. French became an assistant physicist on the metallurgical staff, U.S. Bureau of Standards, Washington, D. C. During his years with the Bureau, he was successively associate physicist, metallurgist, senior metallurgist, and assistant chief, division of metallurgy.

In 1929 Mr. French joined International Nickel as a metallurgist at the company's Bayonne, N. J., research laboratory. Transferring to

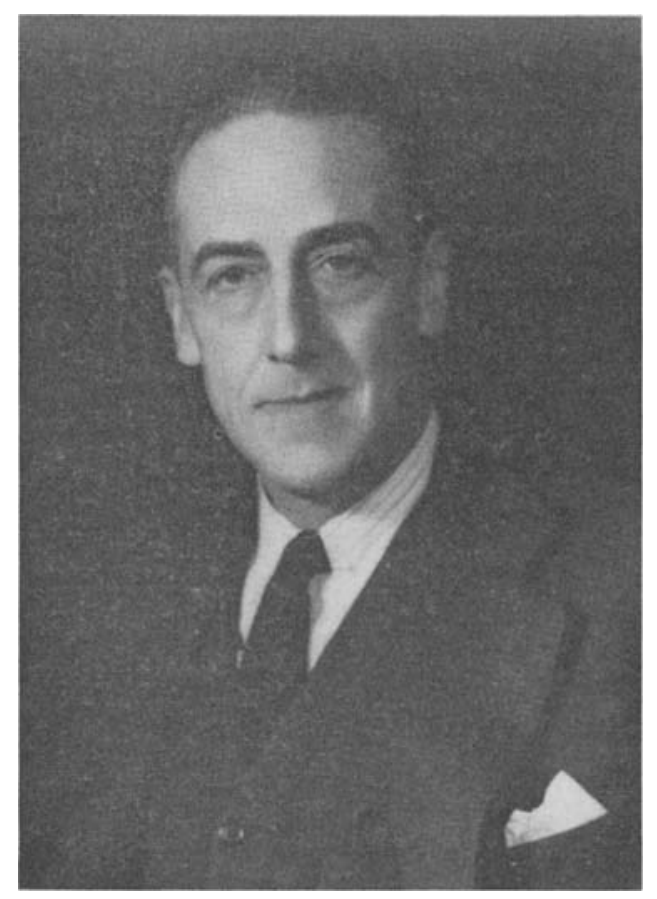

the development and research division, New York, in 1931, he took charge of alloy steel and iron development, . becoming assistant manager of this division in 1943. Mr. French's appointment as an Inco vice president came in March 1947. Previously, he was appointed assistant vice president of the International Nickel Co. of Canada Ltd. in January 1947.

Mr. French served the War Production Board during World War II as senior technical consultant in charge of the metallurgical and specifications section of the iron and steel branch. When this section of the WPB was organized into the steel division, he was appointed chief of the metallurgical branch. From March 1944 to September 1945 Mr. French served as assistant director.

Herbert French was well known not only for his prolific contribution to the metallurgical literature, for which he received numerous awards, but also for his prolonged service to the profession through its technical societies. $\mathrm{He}$ was a past president of ASM, and was the Campbell Memorial Lecturer for that group in 1933. Mr. French was honored by the American Society for Steel Treating in 1931 when he was awarded the Henry Marion Howe Medal. A series of lectures he gave in 1941 before the Fourth Western Metal Congress in Los Angeles was later published in book form under the title Alloy Constructional Steels. 